\title{
Secretary Students' Need: A Content Analysis on English Textbook
}

\author{
Annisa Nur Fatimah \\ \{anisa.nurfa@gmail.com\} \\ Polytechnic of Pratama Mulia, Surakarta, Indonesia
}

\begin{abstract}
The aims of this research are to (1) describe the quality of the existing English textbook used by the secretary students of the college in the teaching and learning; (2) explain the relevancy between the materials presented in the English textbook with the secretary students' need. The data were collected through some techniques, including analysis of the existing English textbook, interviews with the students and lecturers and distributing questionnaire to the students. The data collected were analyzed by using the model of Miles and Huberman, including data reduction, data display, and verifying conclusions [1]. The results of the research analysis are first the quality of the existing English textbook used by the secretary students does not represent the criteria of good a textbook that are adapted from Cunningsworth [2]. Second, the materials presented are categorized as general English; meanwhile, the secretary students need English lessons that focus on a specific field.
\end{abstract}

Keywords: book analysis; content analysis; English textbook; ESP; textbook quality

\section{INTRODUCTION}

English has an important role almost in every aspect of human activities since it has a function as an international language. People tend to use English to communicate with other parties across the country. Furthermore, nowadays is the globalization era; it is in line with the growth of technology that affects information spread fast over the world. Globalization also supports the advancement of trade and business. This situation encourages the emergence of AEC (Asean Economic Community). ASEAN economic community is an integrated economic organization to face free trade among ASEAN countries. This era promotes the use of English in high intensity and vast scope, especially in the workplace context. English proficiency has become essential and a benchmark in the globalization era [3].

ASEAN economic community not only provides a chance trade flow of product and service in ASEAN countries but also gives a chance for the professional worker market. It means AEC will open an opportunity for foreign workers to be at work in Indonesia. Thus, there will be competition for Indonesian in finding a job. Indonesian should improve the quality and skills to face this era. The educational role also influences the increase of quality and skill of human resource since educational institution produces educated and skillful people. Therefore, educational institutions should meet and match the list of subjects that should be taught in ASEAN economic community (AEC) era. Lecturers also should pay attention to learning materials that are presented in the teaching and learning process. The 
materials must be relevant to the students' needs, especially to survive in job competition in the workplace.

One of the skills that should be had by students in AEC era is English ability. English is an international language that is used by many people to communicate. English is recognized as a global language or international language and increases the importance of business, trade, economy, and tourism. People cannot build a relationship with other parties or do trade and business activities without mastering international language [3]. Therefore teaching English at every level is essential. It also becomes government regulation to put English as a subject that should be taught from elementary school to higher school. Teaching English, which is taught continuously at each level, is to help the students having well English mastery and implement it in real communication. Principally, the goal of teaching English varies, therefore educators should analyze the purpose of learning English and then select English learning materials that are suited to the students' background knowledge and need.

Teaching English for the college level should be adjusted with the goal of teaching and learning. A lecturer can analyze it in the syllabus or lesson plan. Generally, the purpose of teaching English for college students is to have the ability to communicate in a real workplace context. The materials which are presented in the textbook should be in line with the students' background and fulfill the students' need. Thus, the kind of materials that are suitable to be presented in the textbook of secretary students is ESP. The materials and the tasks that are available in it should be related to the field. It is crucial to arrange English learning materials to focus on ESP programs for universities, higher schools, and vocational schools [4]. In addition, ESP has an important role as a lecturer's and students' guidance in the teaching and learning process that the content and the goals of the teaching program are suited to the students' needs. ESP materials are unique since the materials and the methods presented are based on the students' need [4].

Teaching and learning English for specific purpose is different from teaching general English. Kind of materials that are taught also will be more specific in a certain profession. In addition, the learning tasks which are implemented in the class will be more applicable in the workplace context [5].

English textbook is one of the essential components of teaching and learning. The textbook has the primary source of learning English in the classroom, [6]. The good quality of a textbook used in the class will influence the output of the teaching and learning process. An excellent textbook should be able to synchronize with the goal of the study program and the curriculum. Furthermore, it also should fulfill the students' needs based on their study background. There is needed a textbook in the learning process since the textbook is the main component of in-class instruction. It guides a lecturer and students to conduct learning activities in the class and what kind of materials that are learnt structurally. There are some descriptions the important of textbook: (1) students will be well organized in the learning process; (2) sometimes, syllabus is provided in the textbook; therefore, the lecturer and the students understand list of the topic materials that they will learn in the semester; (3) textbook provides learning materials and task, those are the main activities that are important in the learning process; (4) textbook will help students to focus to the learning materials that are learnt; (5) learning activities in the class will be more structurally, and especially for lecturer will be guided in delivering materials, [7] 


\section{METHOD}

The technique of data collection are gained through some ways. The first step is the analysis of the existing text book. The textbook analysis is done referring to some aspects adapted from Cunningsworth such as objective, content, language skill, task, topic, methodology and presentation [2]. Second is the interview with the collaborator and the students. The third is distributing a questionnaire to the students.

The technique of data analysis is by using the model of Miles and Huberman, including data reduction, data display, and verifying conclusion. Data reduction covers selecting the data from some sources, simplifying the data, summarizing, and transforming the data that appear in transcript form. This stage is used to choose the important data and delete unimportant one [1].

Data display covers organizing and matching the data to draw the conclusion. This stage is used to describe and show the data into a description, table, chart to show among data relations. While drawing and verifying conclusions is used to find a conclusion through the data meaning displayed into the configuration that shows causality.

\section{RESULT AND DISCUSSION}

\subsection{The Existing Textbook Description}

The existing book is entitled 'Handbook of English 4 (For the Students of Secretary and Business Management) which is arranged independently by the collaborator. The learning materials in the textbook focus on grammar. The title in each chapter is about grammar material. The textbook is used to teach both secretary and management study program. It is also available for internal usage. The book is completed by a preface that mentions the purpose of the textbook in general.

\subsection{Analysis of quality of the textbook}

The quality of the textbook related to the relevancy of the topic and learning materials toward the secretary field and students' need is analyzed based on theoretical construct of some experts, Ur, Skierso in Fauziati, Byrd in Fauziati, and Cunningsworth [2] [7] [8]. 
Table 1 Characteristics of Good Textbook

\begin{tabular}{|c|c|c|}
\hline \multicolumn{2}{|c|}{ 1. Objectives } & $\begin{array}{l}\text { a. The objective of the book should be mentioned in the preface. } \\
\text { b. The objective of the learning material should be described in each } \\
\text { chapter. } \\
\text { c. There is relevancy between material provided in the textbook with } \\
\text { learning goal and student's need. }\end{array}$ \\
\hline 2. & Content & $\begin{array}{l}\text { a. The materials provided are relevant to the student's need especially in } \\
\text { the daily life at workplace context. } \\
\text { b. Presenting grammar and pronunciation materials which are suited with } \\
\text { students' level and need. } \\
\text { c. Presenting vocabulary task as student's activity in improving } \\
\text { vocabulary. } \\
\text { d. The materials provided use authentic material. } \\
\text { c. The materialis provided are initiated by pre-task to build background } \\
\text { knowledge in order to help students' focus in understanding the } \\
\text { materials which are being leant. }\end{array}$ \\
\hline 3. & Language akill & $\begin{array}{l}\text { a. The materials are presented structurally including language skills, } \\
\text { listening, speaking, reading, and writing } \\
\text { b. The reading texts presented are suitable the student's field. } \\
\text { c. The language skill activity provided in the textbook is relevant with } \\
\text { the student'is field. }\end{array}$ \\
\hline & $\begin{array}{l}\text { Exercisen } \\
\text { tasks }\end{array}$ & $\begin{array}{l}\text { The form of exercise or task which is given is various and suitable with } \\
\text { the student's need. }\end{array}$ \\
\hline & Topic & $\begin{array}{l}\text { a. The material topic presented is various covering the four language } \\
\text { skilis. } \\
\text { b. The topic material presented in the textbook is related to secretary. } \\
\text { c. The topics which are presented is suitable with the student's field and } \\
\text { need especially at workplace. }\end{array}$ \\
\hline 6. & Methodology & $\begin{array}{l}\text { The learning materials are arranged based on certain learning method of } \\
\text { tochnique. }\end{array}$ \\
\hline 7. & $\begin{array}{l}\text { Presentation } \\
\text { format }\end{array}$ & $\begin{array}{l}\text { a. Layout, color, and font are appropriate with the student's age and } \\
\text { level. } \\
\text { b. The reading texts presented are readable. }\end{array}$ \\
\hline
\end{tabular}

\section{a. Objective}

Each chapter of the book explains the general and specific goals. They have role in helping lecturer and students to focus on the materials learnt in the chapter.

\section{LESSON 1: \\ NOUN PHRASE}

General Objective: After following class, students understand the concept of a noun phrase Specific Objective: After following class, students can use a noun phrase in English communication

Furthermore, the general and objective descriptions available in each chapter also can help to know the learning outcome after students learn the materials in the chapter. The learning objective mentioned in the preface does not explain the learning outcome for each language skills, including listening, speaking, reading, and writing in detail. The purpose of the textbook is to help the students understand basic grammar, improve vocabulary, and Basic English of students. The learning materials presented in the textbook belong to general English. They are not relevant to the learning purpose of the subject 'bahasa inggris 4 'and do not fulfill the secretary students' need. There are dominated by discussion of grammar material. However, they are not connected directly to their use in the authentic situation.

\section{b. Language Content}

Grammar materials provided in the textbook are integrated with the students' level. There is less of vocabularies task, especially about the terms in the secretary administration office. 
Moreover, understanding technical terms are important for secretary students, especially to help to introduce the kind of activities and equipment or tools in the workplace. There is also no pronunciation practice at all in the textbook.

The existing textbook does not cover listening activity at all. There provides speaking activity; it is to guide the students to actualize their self for practicing English in real communication. However, the learning context given is not related to the students' field. Therefore, the learning materials used are not authentic and do not synchronize with the students' needs, especially in the workplace. Reading materials presented are not relevant to the students' background, for example, the title of the reading text in chapter 1 is 'Health Benefits of Fasting', chapter 5 is 'Pollution', chapter 7 is 'Aunt Helen's House'. Those reading materials cannot build the students' skills and understanding in the secretary field.

The learning materials presented in the textbook are too general and belong to general English. The learning materials available can help the students to improve students' general English in daily life context; however, those cannot fulfill the students' needs in the workplace context.

\section{c. Language Skill}

The existing book does not present the fourth language skills structurally. Not each chapter in the textbook covers listening, speaking, reading, and writing ability, they are not presented proportionally in a unit. The learning materials merely focus on grammar, reading, and writing, in which the context is not related to the secretary field. Therefore, the development of learning materials and tasks for the four language skills in individual or group is needed.

The existing textbook does not present a listening activity at all. The speaking materials available do not represent the students' field, such as in lesson 4 'the life of young people in your surrounding in the digital era', lesson 5 'the worst pollution and throwing waste in the river is destructing environment', lesson 6 'the plus and minus of marriage in the young age', lesson 7 'undergo a strange thing, e.g., meet ghost'. The reading materials available in the existing textbook also do not represent the students' field, such as in lesson 1 'health and benefit of fasting', 4 'Juvenile delinquency', 5 'pollution', 6 'wedding cost', 7 'my Aunt Helen's house', 8 'The Rodriguez Brothers Circus is in town', the following questions delivered do not guide the students to explore the content and explicit and implicit information of the text. The existing textbook also does not provide writing activity maximally. Not all chapters in the book contain writing task.

The book contains grammar materials that the presentations are not really applicative in real life of a secretary. However, pronunciation is important to be learnt since correct pronunciation prevents communication breakdown.

\section{d. Exercise or task}

The existing textbook provides a learning task; however, it is not various; the exercises do not present listening, speaking, reading, and writing in each chapter. A good textbook should provide exercises of the four language skills proportionally to help to improve the students' English ability of the four skills. In the first chapter only present grammar and reading tasks, chapter 2 and 3 are only available grammar tasks, while chapter 4 and 8 only present grammar, speaking and reading tasks. 


\section{e. Topic}

The learning topics are irrelevant with the need of secretary students especially to develop students' skills and experience which is beneficial for the students in the workplace. For example, in lesson 4, there is a speaking task that the topic is describing opinion about a young lifestyle in the digital era and cybercrime. The topic of speaking task in lesson 5 is 'the worst pollution,' and in lesson 6 is marriage at the young age'.

While reading topic in lesson 1 is 'Health Benefits of Fasting', while in lesson 4 is about 'juvenile delinquency'. Those topic materials are not related to secretary background and do not fulfill the students' needs. The secretary students need specific materials to increase their knowledge especially in the secretary field.

\section{f. Methodology}

The materials structure in the existing textbook is not arranged based on a particular learning method or technique. Furthermore, the formation of a learning task for the four language skills provided in each chapter is not proportional yet. There is also no pre-task activity as warming up or building background knowledge of the field to initiate the main activity.

\section{g. Presentation or format}

The existing textbook does not present picture illustration in the pre-task to attract students' focus and to build students' background knowledge related to learning materials that are going to be learnt. There is no picture illustration to give clarity related to the materials that are learnt. The existing book is printed black and white therefore the textbook appearance is unattractive. However, the font size used by the textbook is clear enough and suitable for the students' age and level. The reading texts in the textbook are well printed and easy to be read. Meanwhile, the layout is not colorful; therefore, the textbook is not eye-catching.

Based on the result of the textbook analysis above, it can be concluded some strengths and weaknesses of the textbook to teach secretary students. The strengths of the textbook are: (1) the existing book contains grammar learning and task. Grammar materials are needed by the students especially to help in the process of speaking and writing activity; (2) the existing book provides speaking and reading activities that focus on the general theme. Therefore they can help students to improve English ability in daily communication and interaction.

In other hand, the weaknesses of the textbook are: (1) the textbook does not present listening material at all; (2) the existing textbook does not present the four language skills activities proportionally; (3) topic materials presented in the textbook belong to general English and irrelevant with the students' background; (4) the materials presentation is not arranged structurally and does not refer to certain learning method or technique.

Based on the result of the analysis, it can be summarized that the existing English textbook used by the students is irrelevant and not suitable to be used by the secretary students since it cannot fulfill the students' need and cannot help the students to achieve learning experience that is applicable at the workplace in the future.

Justified to other sources, according to the result of the interview with the lecturer, he states that the learning materials in each chapter covering listening, speaking, reading, and writing. The lecture also states that the module should include specific materials.

According to the result of the interview with secretary students, they mention that the students need English specific material on the secretary field. The result of the interview with the students also gives the same information that the existing textbook does not fulfill the 
students' needs. The language materials and the language tasks are not proportionally presented in four skills, listening, speaking, reading, and writing in each chapter.

While the results of the questionnaires show that the content of the existing textbook is not related to the students' needs and backgrounds. $92,9 \%$ of students agree that the materials presented in the textbook cannot fulfill to help the students in developing English skill especially specific purpose on the secretary. $64,3 \%$ of students agree that they need an English textbook that contains learning vocabularies focus on the secretary field. Not all of the four language skill activities in the textbook available in the textbook. $100 \%$ of students state that there is no listening activity at all in the textbook. Topic materials used in the textbook do not synchronize with the students' field. $92,9 \%$ of students state that there are no listening materials at all that are connected with the secretary. $64,3 \%$ of students mention that the speaking materials presented in the textbook do not have a relation with the secretary. Only $7,14 \%$ of students who state that the reading text in the textbook concern the secretary, while $92,9 \%$ of students agree that the reading texts are not concerned with the secretary. Furthermore, $71,4 \%$ of students argue that writing activities presented in the textbook do not relate to the students' study program.

\subsection{Research Discussion}

A lecturer has a duty to analyze and evaluate the learning textbook used in the instructional activity, whether it is appropriate to the goal of learning and students' need. A lecturer also should match the learning goal and learning materials that are available in the textbook. A textbook belongs to have good quality if it can fulfill the students' needs and help them to improve their skills. Textbooks serve many roles in an EFL classroom, namely teacher, map, resource, trainer, authority, and ideology [9].

A good textbook should provide the components including objective, content, language skill, task, topic, methodology, format, and presentation. The objective is a component of textbook to show the intention description of the learning materials in the textbook. The textbook's aim should correspond and meet the teacher's aim and the students' needs to the highest degree, [2]. A good textbook should contain learning materials that can help the learners to develop knowledge related to their profession in the future. Textbook content should be examined in terms of learners' needs, abilities, and preferences [10].

A good textbook also would present the four language skills, including listening, speaking, reading, and writing proportionally. Materials of the four language skills and their tasks included should help the learners to improve their English skills ability, especially to use it in a real communication context. Therefore, applying authentic materials in the textbook is a good way to help the students learn materials that are really used in real contexts. It can motivate and facilitate the students to master English and apply it in real communication since a good book should focus on acceptable authentic materials that are taken from inner circle societies,[6]. In addition, the textbook also can contribute to achieving this aim by incorporating authentic, creating realistic situations and encouraging learners to participate in activities that help develop communicative skills and strategies, [2].

A good textbook should provide learning material topic that is appropriate with the students' need and level. The topic of learning material and task that is syncronized with the students need, and background knowledge can help them to have a learning experience that is really applicable in real life especially at the workplace. The topics and themes selected were overall appropriate to the students'interests and age, resembling topics they would encounter in real life either in the social, personal, or educational domain[11]. 


\section{CONCLUSION}

Some aspects would be used to analyze the English textbook. The aspects are formulated from a theoretical contract of the experts, including objective, content, language skill, task, topic, methodology, presentation, or format. The researcher also justifies the data by interviewing the lecturer, the students, and distributing the questionnaire to the students.

The result of the analysis from some sources shows that the existing English textbook does not represent the character of a good book since its appearance does not cover the seven aspects. It can be inferred that the textbook is not relevant to be used by secretary students in the teaching and learning process. The materials presented are general English and not specific to the secretary field. The learning materials are inauthentic since they are not close to the real context, especially at the workplace. Therefore, the materials available cannot fulfill the students' needs.

\section{REFERENCES}

[1] Miles and Huberman, Qualitative Data Analysis: an expanded source book (Second Edition), 2nd ed. California, USA: Sage Publication, 1994.

[2] Alan Cunningsworth, Choosing Your Coursebook. Oxford, England: Macmillan Publishers Limited, 1998.

[3] Chia Hui Lin, Wen Chih Wu, and Yin Tsuo Huang, "English for Specific Purposes (ESP) for Hospitality College Students and Hotel Employees in Taiwan," International Journal of Education and Research, vol. 1, no. 8, pp. 1-14, August 2013.

[4] Hussein Ali Habtoor, "English for specific purpose Textbook in EFL Milieu: An Instructor's perspective E valuation," International Journal of Linguistics, vol. 4, no. 3, pp. 44-59, September 2012.

[5] I Gede Budasi, English for specific purpose. Yogyakarta, Indonesia: Graha Ilmu Press, 2015.

[6] Badr Allehyani, Dave Burnapp, and Janet Wilson, "The Place of Inner-Circle Culture in Saudi Secondary School Textbooks," International Journal of English and Education, vol. 6, no. 2, pp. 11-21, April 2017.

[7] Endang Fauziati, eaching English as a Foreign Language (TEFL). Surakarta, Indonesia: Era Intermedia Press, 2010.

[8] Penny Ur, A Course in Language Teaching: Practice and Theory. Cambridge, USA: Cambridge University Press, 1996.

[9] Naji Meidani Elham and Pishghadam Reza, "nalysis of English Language Textbooks in the Light of English as an International Language (EIL): A Comparative Study," International Journal of Research Studies in Language Learning, vol. 2, no. 2, pp. 83-96, April 2013.

[10] Biljana b. Radic Bojanic and Jagoda P Topalov, "Textbooks in the EFL Classroom: Defining, Assessing, and Analyzing," Languages and Cultures across Time and Space Journal, vol. xlvi, no. 3, pp. 137-153, September 2016.

[11] Thotapally Arjaneyulu, "Critical Analysis of the English Language Textbooks in Andhra Pradesh, India," International Association of Research in Foreign Langugae Education 
and Applied Linguistics, ELT Research Journal, vol. 3, no. 4, pp. 181-200, 2014. 